\title{
Back on Track: Exploring how a Further Education college re-motivates learners to re-sit previously failed qualifications at GCSE.
}

Underachievement at GCSE level has significant effects on an individual's life chances.Each year, around half of 16-year-olds leave school without having achieved a full level two qualification (five GCSEs at $\mathrm{A} *_{-} \mathrm{C}$ including English and maths).Many of these students enrol on a programme of study at local Further Education (FE) colleges. Recent Coalition government reforms, including Raising the Participation Age (RPA) and compulsory English and Maths study up to aged 19, have reaffirmed FE as an agent to improve students' life chances andact as a catalyst to reduce youth unemployment. FE colleges provide a 'second chance' for learners who have failed at school. This research shows students who have previously attended low-performing schools, arrive with low motivation, low levels of self-efficacy and a negative perception of education.

Focus group discussions with GCSE resit students studying at FE, followed by individual interviews, revealed that school experience of unprofessional teacher-pupil relationships, a lack of discipline, inconsistently applied sanctions, a lack of academic support and prevalent low level disruption all contributed to demotivating the students. The data revealed students' experience at college was significantly different when compared to secondary school. Professional and supportive relationships with teachers, classroom management strategies leading to learner ownership and autonomy, consistently applied behaviour management practices and visible senior leadership, enabled learners to reengage in education at FE and successfully resit their GCSE qualifications.

Keywords:further education (FE); motivation;self-determination theory (SDT); educational engagement; classroom management; low-level disruption.

\section{Introduction}

Failing to achieve expected educational outcomes by pre-determined ages can have a significant impact on an individual's life chances and opportunities (Centre for Social Justice2013). Research has shown academic achievement is linked to a range of factors including, ability and home and school experience, and there is now increased attentiongiven to 'school-based factors that appear to foster academic under-achievement' (Kenny et al. 2010, 205).

The current government expected attainment levels at age 16 is a full level two qualification offive GCSEs (or equivalent) including English and maths, at grades $\mathrm{A}^{*}-\mathrm{C}$. 
Good GCSEs are 'fundamental to young people's employment and education prospects'(Wolf 2011, 8). The 2010-15 Coalition government signalledthe importance of education by introducing a number of significant reforms for post-16 education, including Raising the Participation Age (RPA), which requires all school leavers to 'remain in some form of education or training' (DfE2013) up to the age of 18. A renewed emphasis on English and maths study requires 'any student who has not achieved grade $\mathrm{A} *$ to $\mathrm{C}$ in maths and/or English GCSE, by age 16, to continue to work towards achieving these' (Education Funding Agency 2014, 3) becoming a condition of government funding from August 2014 to ensure that institutions are operationally bound to these reforms.

Students who do not achieve a full level 2 qualification at 16often have limited options and many choose to study at FE as it 'has come to be seen as a progression route for those who have failed at school' (Wallace 2013, 348). Research suggests 'the aspirations of learners in FE tend to be lower than those learners who continue their post-16 education in schools' (350).For some learners academic study requires 'a greater degree of endurance and effort' (Lumby 2012, 271), and many learners 'do not remember school as a happy experience' (Morrison 2010, 73). These experiences are important if we are to understand what possibly motivates students when they transition to FE.

\section{Research Environment}

This research was conducted at a large General Further Education College (GFEC) in the East Midlands. The college is one of the two largest in the City, with approximately 20,000 students enrolled, of which 8500 are on full time courses. Provision is offered to students aged 14+ with no upper age limit. The college provides a broad curriculum, vocational and academic, across subjects, industries and the arts, at levels ranging from pre-entry all the way to degree level qualifications. The college has a number of campuses across the city as part of its estate, with the research conducted at the central campus based in the city centre.

Socio-economic deprivation is a characteristic of the city, influenced partly by the economic recession and subsequent central government austerity measures, with 8\% ofresidents classified as long term unemployed (Census 2011), the eighth most deprived conurbation in the UK. When compared to the national picture, the city has higher numbers of lone-parent households, higher numbers of residents with no qualifications and those who are employed are more likely to take up low-skilled, routine occupations.

The city is currently under close review as a large proportion of its secondary schools have been placed in 'special measures'for'failing to give its pupils an acceptable 
standard of education' (Ofsted 2015a, 17). The release of GCSE league tables has further compounded the City's educational issues as it has the 'third-worst GCSE pass rate in England' (Russell 2015) being ranked '150 out of 152 education authorities nationwide' (Russell, 2015).

FE has been subject to a 'reduction in funding of 25\%' (Department for Business Innovation \& Skills, 2012, 6). With further Austerity measures expected in an increasingly measurement focused culture;fiercer competition for students; and funding linked to learner outcomes;success, retention and achievement rates are more important than ever in FE. The college has a GCSE Academy which providesa fast track 36 week GCSE programme to learners aged 16+ who have not yet achieved a full level two qualification. The Academy has achieved considerable academic success with these students. The Academy GCSE results for $2012 / 13$ were $43 \% \mathrm{~A}^{*} \mathrm{C}$, with the national average for the sector inMaths being 7\% and English 6.5\% (Ward 2014). GCSE results for 2013/14 were '56.1\% A*-C grades achieved with the national average for the sector being 15.4\%' (Performance Panel Data $2014,1)$. This success has been achieved within a context of recruiting students from schools identified as some of the poorest performing in the country, where behaviour has been reported as poor and underachievement is high.This research seeks to explore how these learners' school experiences affected their motivation and whether the Academy's success, couldbe linked to motivational teaching strategies used in the Academy to reengage learners who had previously failed GCSE qualifications.

\section{Motivational Theory}

While teachers may hope learners arrive ready to learn, colleges and schools must consider how they can work toincrease motivation as 'the psychological climate of the educational experience [has] prominent influence upon the amount and type of learning which takes place' (Rogers 2003, 396). Motivation is a significant contributory factor to learning, behaviour and achievement with research from Alt $(2015,111)$ indicating that it is also linked to greater 'persistence in college'.

Motivation can be dividedinto intrinsic internalised motivation, which produces internal gratification and enjoyment for engaging with an activity; and extrinsicmotivationis predicated on external rewards(Alt 2015; Kirby et al. 2015; Dietrich et al. 2015; Guyan 2013; Baird, Rose, and McWhirter 2012; Wallace 2007a). Behavioural theorysuggestsexternal rewards such as praise,awards and certificatesmay'increase the desire to pursue a goal' (Gould 2012,17) but the impact may last only 'as long as it takes to 
gain the resultant rewards' (18). Alt $(2015,112)$ suggests that extrinsic or a 'surface approach' to motivation is linked to 'low quality outcomes of learning' (112). Conversely, intrinsic motivation produces longer lasting internal effects (Gould 2012) for learners, including 'higher concentration and better time management' (Alt 2015, 112).

Self-determination theory (SDT) focuses on the degree in which behaviour is selfmotivated, self-determined and autonomous(Kirby et al. 2015; Alt 2015; Guyan2013; Baird, Rose, and McWhirter 2012). Autonomous or intrinsic motivationhas been associated with positive outcomes, such as interest, enjoyment, enthusiasm and higher academic achievement (Alt 2015; Baeten, Dochy, and Struyven 2013). SDT stipulates that for autonomous motivation to be achieved, a number of conditions must be met within education including, competence, autonomy and relatedness (Dietrich et al. 2015; Kirby et al. 2015; Nguyen 2015; Baeten, Dochy, and Struyven 2013; Guyan2013). Where teachers can create a climate to 'assist learners to internalise their motivation of externally regulated activities' (Guyan 2013, 2), students are successful.

Some students who attend under-resourced schools may have developed a belief that academic outcome does not correlate with effort or that school achievement is not important (Kenny et al. 2010), further, students experiencing low levels of motivation are likely to develop 'weak coping strategies in the case of failing' (Alt 2015, 112). These experiences can negatively affect student perceptions of education and their motivation to learn in the future. This is important to college tutors because motivation is the 'energising force that initiates and sustains behaviour and ultimately produces results' (Guyan 2013, 1). Ormrod(2008, 384-385) suggests increasing motivation, 'enhances performance; increases initiation of and persistence in activities; leads to increased effort; affects cognitive processes' and further, Carreira (2011) claims motivation produces increased productivity, work rate and achievement levels.

\section{Teaching to Increase Motivation}

Behaviourists, such as Skinner, have identified positive reinforcementhelps motivate students as 'learning is encouraged by an external reward of some description' (Gould2012, 17) and operant conditioning can support behaviours 'more or less likely to occur in a given situation' (Skinner 1974, 181). In operant conditioning the stimuli that 'increase the likelihood of a response, are termed "reinforcers" whereas those that decrease the likelihood of a response are termed "punishers' (Roessger 2012, 571). Within a teaching situation, teachers often reinforce desired student behaviour by offering rewards and punish negative 
behavioursto reduce the likelihood of future occurrence. However, operant conditioning used alone to tackle behavioural and motivational issues 'may give rise to feelings of anxiety, fear, anger or resentment in the recipient which can exacerbate rather than solve behavioural problems' (Gould 2012, 38). If used indiscriminately, external motivation may become a normal expectation and lose its effect as a reinforcement strategy (Gould 2012).Macleod (2006, 160) argues learners are 'in need of support rather than punishment'which correlates with research demonstrating the most successful classroom management approaches were 'humanistic strategies, and the least effective being the most authoritarian' (Reupertand Woodcock2010, 1263).Self Determination Theory (SDT) develops the humanistic approach by aiming to increase intrinsic motivation through developing student competence, autonomy and developing personal relatedness.

When students do not see themselves as competent their achievement is lower(Kirby et al. 2015; Nguyen 2015; Leaper, Farkas, and Brown 2012) and learners who are intrinsically motivated have a more 'favourable perception of their academic ability' (Carreira 2011, 91). Self-efficacy is influenced by previous learning experience (Slack, 2014) further, high levels of self-efficacyhelps learners feel more in control of their own learning' (Ewen and Topping 2012, 232). This self-efficacy is further supportedthrough teaching methods which are'learner-centred, participatory, interactive, and involve group deliberation(Mezirow 1997, 10). Learner centred teaching methods, 'reinforce learner selfefficacy (Nguyen 2015, 704), promote students being at the centre of the learning experience and not only increase motivation to learn, but also have a positive effect on the depth of learning, understanding, and retention of knowledge (Baeten, Dochy, and Struyven 2013).

Autonomy support strategies contribute towards creating an environment which encourages students to become independent learners and exercise a degree of selfdetermination. Successful strategies'minimize the use of pressures and demands such as explicit rewards andpunishments' (486). SDT does not dissimulate classroom management, but uses techniques where learners' needs are foremost,and fosters an environment where'the teachers needs for order, obedience, and compliance' (Stoughton 2007, 1033)are subsidiary to the 'students' needs for understanding, growth and responsibility' (1033). Other research has shown learners who feel autonomous, have internalised motivation, engage in class activities for enjoyment and for personal achievement rather than gaining external rewards or avoiding censure (Kirby et al. 2015; Mouratidisand Michou2011). 
Relatedness refers to the degree of belonging that a student feels in a given classroom environment. Contemporary research indicates that disaffected learners point to 'unapproachable teachers' (Nguyen 2015, 701) and subsequent 'negative relationships' (Lumby 2012, 263) as being a significant factor contributing to their lack of motivation.Teachers need to reflect on how 'their disposition towards learners has a major impact on [students] willingness to engage and learn' (Ledingham, 2008). Evidence suggests that students who feel cared for, feel important and have supportive teachers, display higher levels of engagement and tend to do better academically and socially in education (Dietrich et al. 2015; Nguyen 2015; Kenny et al. 2010). Classroom management strategies need to be negotiated with learners, apply to both students and teachers and be treated as normalised expectations, rather than existing as self-supporting control mechanisms (Baeten, Dochy, and Struyven 2013; Wallace 2007b). Further, by showing a genuine interest in learners' decisions, teachersimplicitly communicate to learners that they are valued as individuals (Baeten, Dochy, and Struyven 2013; Gravells and Simpson 2008).

\section{Methodology}

This enquiry was informed by humanistic principles. Its principle aim was 'capturing the experiences that help us understand what we might do to change, manage or reproduce these experiences' (Newby 2010, 36).

The participants were drawn from the 120 students enrolled on the fast track GCSE programme. The majority of the possible participants were aged from 16-18, but the sample group also had a large number of students aged 19 and over, with the largest group being 16 year old school leavers. 'Purposive sampling' was used (Punch 2005, 187) to select the final eight participants. The sampling approach enabled the inclusion of males and females; native language speakers and non-native language speakers; and a range of ethnicities. The final sample consisted of four females andfour males, of whom fourwere black, Asian and minority ethnic (BAME),oneof those being English Speakers of Other Languages (ESOL), and was representative of the 16-18 year old students in the complete cohort of 120 students. Purposive sampling allowed participants to be 'selected on the basis of personal attribute(s) that [were] relevant to the purposes of the research' (Denscombe 2010, 182). Participants satisfied the following criteria:

- Aged 16 on $31^{\text {st }}$ August 2014;

- Attended a state-funded secondary school in the City's geographical boundaries; 
- Attended a school placed in 'Special Measures' at last Ofsted inspection;

- Attended such schools immediately before transferring to FE; and

- We're willing to engage in the research project.

Six of the eight participants were eligible for Free School Meals (FSM) while in compulsory education, giving an indication of their socio-economic background. Participants who had recently attended local schools, were initially selected, so their reflections and insights were as current and would, accepting the limitations of memory, be as accurate as possible. Interviews were conducted a third way through the GCSE course, in December 2014, giving the participants both an opportunity to adjust to a new learning environment and to benefit from 12 weeks of non-school education.Purposive sampling sometimesproduces a non-representative sample, however, this sample group accurately reflected the wider cohort and provided 'sufficiently rich, valid data'(Cohen, Manion, and Morrison2004, 109) to explore the research topic. As this was a small scale situated research project, it was not intended 'to generalise findings beyond the question' (102). Acknowledging the research participants as young adults who were sufficiently competent to make their own decisions, consent was first gained from each of the participants. However, because the participants were under 18 years of age, informed consent was received via parents and/or guardians providing transparency. The participants could withdraw from the research at any point.

Data was collected through one semi-structured group interview, andtwo fully structuredindividual interviews. This approach was used to capture the participants' experience of education at school and college and to 'explore attitudes and perceptions' (Denscombe 2010, 177).Participants selected pseudonyms to provide anonymity and were briefed before and after the group interview on the issue of confidentiality. The aim was to 'establish a climate of trust within the group' (182) where participants felt 'sufficiently comfortable to express themselves freely' (182) to support in the production of a rich data source.During the data collection process, 'deliberate naivety' (174) was adoptedto encourage 'openness' of response, to facilitate 'new and unexpected phenomena'surfacing (Cohen, Manion, and Morrison2004, 273) and to help minimise the impact of researcher bias.During research interviews people may 'respond differently depending on how they perceive the person asking the questions' (Denscombe 2010,178). All primary interview data was collected while employed at the Academy as part of the teaching team. To 
facilitate data collection and to reduce any potential negative impact on being an Academy staff member, a group interview was chosen as the most appropriate method to provide participants maximum 'flexibility and freedom' (Cohen, Manion, and Morrison 2004, 273). The group interview also allowed participants to formulate ideas amongst themselves as 'knowledge is being constructed between participants' (267), which would be unattainable 'without the interaction found in a group' (171), and provided further guards against researcher bias. Researcher bias was alsominimised by using broad, open ended questions which put the participants under 'minimum restraint on the answers and their expression' (275), with the semi-structured questions used as a method of 'discovery rather than checking' (Denscombe 2010, 182) with 'probes' and 'prompts' used to provide loose guidance to and elaboration when needed, to support clarity of the data.This relatively unstructured initial approach encouragedauthenticity and helped to produce 'frank and open responses' (Cohen, Manion, and Morrison 2004, 276) as well as 'producing data and insights that would be less accessible through more structured approaches'(Punch 2005, 171). In this way participants were enabled to provide a personalised, situated response and to express their understanding and experiences of re-siting GCSEs at college. To counter the possibility participants might provide answers that were constructed 'to fit in...be correct or...fulfil a social role' (Crutchfield 1955, 194), two individual interviews were held after the focus group interview to balance out any effects of group conformity. Validity was promoted through triangulation of the methods as it is possible to 'look for themes emerging from a number of interviews'(Denscombe 2010, 202) and to 'check whether there is some level of consistency' (201).

All of the interviews were audio recorded and transcribed in full. To support participant ownership, all transcripts were shared with the group so that they could confirm the accuracy of the data and 'to see whether the essence of the interview [had] been accurately and fully captured' (Cohen, Manion, and Morrison 2004, 371). The final research write up was also made available to the research group. Data was analysed through extensive coding, allowing key themes to emerge. The data extracted from the focus group interview was initially coded to identify broad themes, used to help inform questions for the two individual interviews. The full data set was then re-analysed to establish if there were any new emerging themes, and to establish if there were any regularities and recurring themes across all interviews. However, attention was also given to pertinent 'themes that [were] unique to a single interview or a minority ofthe interviews' (371). A process of categorisation or 'unitising', was used to 'create overarching codes for each cluster' (479). 
Key themes were then analysed against current educational research to identify validity, policy context and a sample of participant responses to support findings. The data produced four clusters of data, which subdivided into seven key themes:

(1) Student Understanding of Motivation

(2) Teacher-Pupil Relationship

(3) A Second Chance

(4) Classroom Management

(5) Discipline

(6) Academic Support

(7) Class Size

Each of these themes is discussed in detail in the "Findings' section.

\section{Limitations}

While the findings of this research are illuminative, it is important to acknowledge the limitations of the research. This research was conducted with eight participants of mixed genders and from different BAME groups in a large city centre GFEC. As such, this research may have greater relevance for similarly situated colleges. While the Academy worked hard to use teaching strategies to maximise student achievement, it is difficult to state absolutely that these strategies produced high student achievement. It is possible that as they have become older most learners became more responsible for their behaviour and conduct while in college. Further, research suggests the presence of older learners in the student cohort, as was the case in this research project, has a'positive effect on younger students' (Porter 2015, 14). Again it is not possible to quantify the effect of the presence of older students. Finally, the learner's perceptions of school education are based on memory and have been mediated through time and emotion, which could adversely affect accuracy.

\section{Findings}

Data analysis produced seven key themes which are organised around four clusters: Personal Agency (theme 1 - Student Understanding of Motivation); FE Ethos (theme 2 Teacher Pupil Relationship, theme 3 - A Second Chance); Behaviour Management (theme 4 - Classroom Management, theme 5 - Discipline); Academic Management (theme 6 Academic Support, theme 7 - Class Size).

\section{Student Understanding of Motivation}


It was important to establish what the participants already understood by motivation and its effect on achievement. They expressed that it effected how much they wanted to pursue a task, how hard they worked during the task and the amount of work they would ultimately produce:

I think motivation is important, cos it's just like, if you're motivated you wanna do it and if you're not motivated you don't want to (Marshall)

With no motivation you can kind of go off track from what you're meant to be doing (Marcus)

Motivation can also potentially affect other things, not just your grades, but also attendance and other stuff like that (Nasir)

When asked how motivated they felt at secondary school, all participants vigorously expressed they felt demotivated. The participants believe that this demotivation led them to complete little work, and be:

Sat in some lessons doing nothing (Amy) or

Mess about a lot (Marcus)

The participants understanding of motivation and its effect on conduct and achievement resonates with Ofsted $(2008,4)$ research which defined demotivated learners as those who display one or more of the following behaviours:

(1) 'regularly non-compliant, but not aggressive or threatening,

(2) regularly disruptive, challenging or both,

(3) absent for $20 \%$ or more of the available sessions in the year,

(4) quiet, withdrawn and uninterested in most lessons.'

\section{Teacher Pupil Relationship}

The delicate interactionsbetween teacher and pupil can be decisive in student learning. The research findings suggested confusing relationships were built with the learners while at secondary school, which blurred the lines of professional boundaries, consequently 
nullifying the teacher's ability to provide the appropriate conditions to motivate students to learn:

With some teachers you'd be friends with them more than they'd be your teacher (Ruby)

Instead of learning, you'd be talking to them like their your friend, which I suppose doesn't help (Nasir)

Furthermore, a link was made between seeing a teacher as a 'friend' and the difficulties this created with discipline:

When you're friends with them it makes it harder for them to motivate you cos they can't be strict when telling you to do stuff cos you obviously see it as funny (Marshall)

Yeah, then you'd see them stressing when the class ain't listening (Amy)

They'd shout at us to get us to listen but it makes you switch off (Marcus)

Research from Ofsted $(2014,7)$ found that 'when teachers blur the boundaries between friendliness and familiarity, pupils too often demonstrate a lack of respect for staff by talking across them or taking too long to respond to instructions'.

When questioned about relationships with teachers at college, the participants were clear they were significantly different and how this affected their motivation to learn:

It's a lot more professional I'd say. You can call them by their first name instead of like Sir, so it makes you feel like on their level (Marshall)

They sort of like, stick to their job (Nasir)

They are a lot more serious but you know if you need to talk to someone you can talk to a teacher. They're more open (Amy) 
They don't treat you like they're your friends either. They treat you like they need to teach stuff, like it's serious (Marcus)

They don't belittle you or just order you about. They ask you instead. It's more friendly. (Aaron)

They treat you like people, not just a kid (Ruby)

Although the learners now addressed teachers by their first name, they did not consider this unprofessional. Conversely, it promoted a "more "adult" environment in college with the way the students perceived they were treated by school teachers (Harkin 2006, 325).

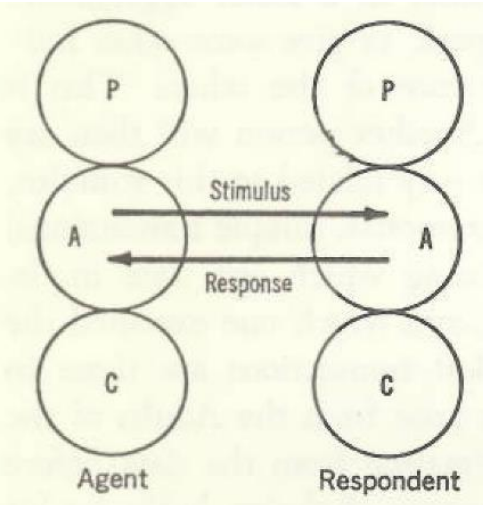

(Berne 1964, 30)

Berne's Transactional Analysis (TA)studies the 'transactions that [occur] between people when they communicate' (Stuart and Algar 2011, 8). The theory stipulates that with each social interaction, between two or more people, there is a 'transactional stimulus' (Berne 1964, 29) delivered by the agent and the response provided by the recipient,is termed the 'transactional response' (29). Within a Parent-Child interaction, the aim for the agent is to assert control, with the transactional response often resulting in conflict.Adult-Adult interaction is most effective as transactions are complementary and each party interacts and responds to eachother at a similar level (Berne 1964; Berne 1963). Further, research conducted by Stuart andAlgar $(2011,9)$ suggests 'the use of TA in the classroom improves behaviour, [leading] to a more conducive learning environment and raising academic standards'. 
SDT indicates that 'students are influenced by the way teachers communicate with them' (Kirby et al. 2015, 2), With FE Colleges afforded 'the opportunity to develop a different set of relationships between staff and students' (Peart 2013, 34) and communication based on adult-adult transactions, students felt they were respected as individuals.

\section{A Second Chance}

Statistics on the destinations young people choose after they complete school study aged 16, reports that 'students with lower grades at GCSE will often move into FE' (Porter 2015, 5). Analysis of the data demonstrates participants understanding of the 'second chance' (Attwood and Croll 2004) nature of their Further Education studies, while the findings suggest high expectations from teachers helped to positively reinforce this message:

They [teachers] know that this is probably your last chance to get a good GCSE and they wanna help you more (Amy)

Everybody has been given a second chance, so we don't wanna mess about and lose it (Aaron)

\section{Classroom Management}

'The quality of education is dependent on both resources and teachers' ability to manage student behaviour' (Nooruddinand Baig2014, 3). Thisresearch suggests that a demotivating factor for the participants was they often felt issues of classroom disruption were not dealt with effectively at school:

\footnotetext{
People would be talking when the teacher was talking and it would be hard to understand what you wasmeant to do (Ruby)
}

Some teachers couldn't control the class so it was hard to get work done. It would be loud (Aaron)

Low level disruption has been described as 'anything that slows down the flow of the lesson' (Bennett, 2011). Ofsted $(2014,4)$ categorised features of this behaviour as follows: 
- 'talking unnecessarily or chatting

- calling out without permission or over others

- being slow to start work or follow instructions

- showing a lack of respect for each other and staff

- using mobile devices inappropriately'.

Research conducted by Nooruddinand $\operatorname{Baig}(2014,2)$ indicates that disruptive 'students may interrupt lessons or make it impossible to continue', rendering learning incapacitated, with the teacher and/or students attention diverted for a period of time. Ofsted $(2014,4)$ found that low level disruption meant 'pupils are potentially losing up to an hour of learning each day... equivalent to 38 days of teaching lost per year'. Such breaks in learning can contribute to demotivation, for both the perpetrators and other learners in the classroom. Instances where teachers were felt to have not resolved behaviour issues, similarly contributed to demotivation:

Kids who disrupted a lot didn't get punished and the teacher would waste time helping them with the work more than me...it didn't make me feel good cos I could have got a better grade than I got if the teacher didn't waste time on them who mess about (Marcus)

Yeah, so you think what's the point ... you just talk to your mates more (Amy)

They did sometimes...the teachers would just say, 'stop talking' but if you carried on talking after that they wouldn't do anything so you get away with it. There was no consequences (Marshall)

In any classroom, for management strategies to be effective, classroom expectations should be clearly communicated, applied fairly and most vitally, consistent (O’Donnell 2005).At college, research participants reported that disruption levels had significantly changed and there was:

Very little (Amy) 
Barely any (Aaron)

Not much disruption (Ruby)

The research suggests instances of disruption were addressed consistently and behaviour systems and procedures utilised:

There have been peoplewho disrupt lessonsbutif they don't listen to the teacher and carry on they get taken out (Aaron)

The people who disrupt the lessons get sorted out, rather than them staying in the lesson and keep disrupting it for all of us (Marcus)

The group further added, this supported their college experience because:

It's more easier to concentrate (Nasir)

It's better cos you get more learning done and you learn that you shouldn't disrupt other peoples learning either (Amy)

\section{Discipline}

Discipline emerged as another recurrent theme and in particular how the presence of senior management could support motivation, whereas their absence contributed to demotivation. Participants felt at school, senior management were often weak, not visible or lefttoo often:

At my school we didn't really have one head teacher full on for my time, they were just coming and going, so there was very little, erm, can't think of the word...discipline (Nasir)

My head teacher kinda gave students like a free role... y-kno how (the Head of GCSE Academy) comes into classrooms and everything and walks around the college, my head teacher didn't do that (Marshall) 
My motivation was affected cos I knew I could get away with things, like if you got detention and didn't turn up nobody would check (Marcus)

My head teacher would try to be strict. He'd shout and stuff if he came into class but not follow through with threats (Amy)

'Systemic inequities could negatively impact student learning by undermining motivation' (Kenny et al. 2010, 205): a nationwide Ofsted $(2014,6)$ report concluded that some teachers, those mainly located in underperforming schools, believed management were not 'high profile' enough around the school, highlightingthat 'senior leaders did not assert their authority'(6).

At college, the participants were aware of disciplinary procedures, and the consistent application of these procedures by all staff and the high-profile visibility of senior leaders (Head of Academy) both in classrooms and around the campus, contributed to their motivation to learn:

When I come here teachers are asking me, prompting me to give in homework and stuff like that. Keeping me on track (Marcus)

You see (the Head of GCSE Academy) coming into classes and taking students out who mess about or don't attend and stuff (Amy)

Now I know if I do something bad that something bad will happen to me... it motivates me cos I know I have to attend and if I don't someone will be chasing me. I want to work more and try harder (Marshall)

Research from Noorrundin $(2014,5)$ concluded that 'when the head teacher [is] seen walking the corridors, visiting lessons and, most importantly, acting against indiscipline, this support[s] classroom teachers and motivate[s] students', emphasising the importance of increased visibility of head teachers and senior leaders to enforce student disciplinary issues (Noorrundin 2014; Ofsted 2014) and the tacit appreciation of students', as demonstrated by the comments above, of clear boundaries.

\section{Academic Support}


Perceived academic support from others predicts motivation (Leaper, Farkas, and Brown 2012) and teacher support has a positive influence on enhancing students' academic motivation (Dietrich et al. 2015; Nguyen 2015;Jasmi and Hin2014). The research findings suggest that the participants felt that support with work and classroom activities was limited at school, in particular in large classes (defined by participants as 20+). The participants identified that this resulted in less teacher contact,making it harder to understand tasks and complete work:

I didn't understand what to do, we wouldjust get shouted out for not working but the teacher wouldn't tell me what I'm meant to be doing (Ruby)

Research conducted by Jasmi and Hin $(2014,76)$ suggests that a 'lack of support from the teacher leads to a decrease in motivation, especially when (students) feel that they cannot complete the task given':

If I don't understand the work I get easily distracted (Marshall)

Teachers should make sure we understand the basics before moving on (Nasir)

Actually tell me what I'm meant to be doing(Amy)

Behaviour management theorysuggeststhat 'learners' poor behaviours and lack of motivation may be due to some deficiency in the standard of teaching they receive' (Wallace 2013, 347). Petty (2009, 103) claims 'most of the discipline difficulties experienced by teachers in the classroom are created before the lesson started'. The relationship between supportive, engaging teaching methods and levels of disruptive behaviouris paramount.

The participants indicated that the support provided by the teachers at the GCSE Academywas motivating and helpful:

Even if you're not confident enough to put your hand up, the teacher will always check you understand what you're doing (Marshall) 
They try to teach you enjoyment for the subject too, not just what you need for the exam (Aaron)

Danielsand Arapostathis (2005)claimedeven reluctant learners become more motivated when they receive teacher support, confirming teacher support is an effective motivating factor in the classroom; '[when] people are in an environment where they feel cared for and important, the experience of intrinsic motivation increases' (Dietrich et al. 2015, 46).This support was also effective when complemented by peer-to-peer support:

Everyone wants to study, so they're all tryin' to help you get the same grade they wanna get or even higher (Marcus)

Everyone encourages each other even with little things like remembering when homework is due or studying together in the cafeteria (Amy)

Research from Leaper, Farkas, and Brown (2012) demonstrates peer support is an important, often overlooked,factor that affectsrelatedness and group belonging. Further, students' motivation for learning and achievement increaseswith peer cooperation (Baeten, Dochy, and Struyven 2013; Leaper, Farkas, and Brown 2012) and helps to support a positive perception of learning (Slack 2014), which in turn increases educational achievement, demonstrating the importance of group interaction and the significance of teachers creating a collaborative, cohesive environment.

\section{Class Size}

The research findings suggest the participants felt academic support received from the teacher while at school, was reduced in large classes, resulting in less teacher contact. The participants categorised large class sizes as those containing $20+$ students, with indication of class sizes closer to 30 in some subjects. The participants reported that this made it difficult to receivesupport and affected the amount and type of contact with the teacher:

If it was like a really big class it was hard cos you wouldn't get much support and it was hard to like just talk to the teacher (Marshall) 
They [teachers] get annoyed when you don't know the answer and then unhelpful. (Amy)

They're not really paying attention to you (Marcus)

I had no support (Nasir)

Educational research correlates the positive effectives of small classesas an increase in learning and higher student achievement (Mueller 2013; Bruhwiler and Blatchford 2011; Cheng 2011). The GCSE Academy has an average class size of 18. The participants identified classroom contact with teachers in the Academy as being more available and supportive:

The teachers help you more (Marshall)

The teachers come round and check if you're ok or struggling with the work (Marcus)

Research from Cho, Glewwe and Whitler $(2012,77)$ reported that 'smaller classes allow teachers to provide more attention to each student' and 'reduce[d] time spent disciplining disruptive students'(77). Further, research from Bruhwiler and Blatchford (2011, 96) purport that this 'benefit[s] low attaining and disadvantaged students in particular'.

\section{Conclusion and Recommendations}

Research suggests that since the Wolf recommendations, students leaving school without a grade $\mathrm{C}$ in English or maths were 'much more likely to choose to attend [an] FE college' (Porter 2015, 4) against other post-16 options such as school sixth form. The ETF $(2014,4)$ reports 'three quarters of full-time students who have not achieved a maths GCSE at grade C or above, by the age of 16, enter FE colleges' concludingthese learners are more likely to report 'negative prior experiences with learning' (5) often making 'learner engagement particularly challenging for teaching staff' (13). These issues are particularly pertinent as students are required to continue the study of these subjects, as a condition of funding, until they achieve a grade $\mathrm{C}$. 
For many learnersFE represents a change in educational culture (Wigley 2004). This research identified many changes in the students' college experience since starting the GCSE programme, and they had been re-motivated since arriving from various low performing city schools. Demotivating school factors wereunprofessional teacher-pupil relationships, low level disruption, lackof discipline, lack of academic support, large class sizes and low visibility of senior staff.

Learners are more likely to display behaviour regarded as disruptive, if theydo not understand the work setor have a poor student-teacher interaction, nonetheless, Ofsted claims schoolsin special measures often have inadequate teaching, leaving learners uninterested and prone to misbehaviour. In college, teachers work to provide support to learners, clarity for teaching tasks and build up positive, professional relationshipssupporting relatedness. The findings correlatewith recent research reporting disengaged learners are supported to achieve previously failed qualifications when a 'good rapport is built with teachers and trainers' (ETF 2014, 5). This allowed the learners to commence tasks confidently and reduced the possibility of misbehaviour; 'the most efficient way to eliminate misbehaviour is to prevent the occurrence or escalation from the beginning' (Nooruddinand Baig2014, 2). Teaching supports SDT, competence and relatedness, as learners were sufficiently informed to complete tasks and 'view themselves as being competent' (ETF 2014, 5). This was achieved through clear instructions and a more supportive learning environment where students felt'safe to try and to learn' (Jasmi and Hin 2014, p.81). Further, recent research suggests 'smaller class sizes of smaller groups with high staff ratios' (ETF 2014, 13)support the teaching of disengaged students. The research participants of this study reported smaller class sizes represented an increase in teacher contact and support available in the classroom.

Further interrogation of the data revealedFE teacherswereunwilling toignore poor behaviour (Kidd and Czerniawski2010)to prevent feelings of injustice. In low performing schools, oftenbehaviour management systems were not applied consistently by staff and misbehaviour was left unchallenged (Ofsted 2014). This is consistent with the findings of this research. The participants pointed to the lack of discipline from senior management at school and how this demotivated them. In contrast, at college theHead ofGCSE Academy made an explicit effort to behighly visible in classrooms and corridors, interacting regularly with learners and reprimanding students who failed to adhere to expected college standards. The data suggests that the College Academy adopted a collaborative approach to behaviour management, with senior management being highly supportive of its teaching staff. 
Behaviour systems were implemented consistently by staff andthe success of these strategies was indicated by learner autonomy, 'relat[ed] to students' feelings of personal control' (Nguyen 2015, 695),correlating with current research from the ETF $(2014,5)$ which identified that for disengaged students re-siting failed maths qualifications, 'self-motivation is encouraged by giving them greater control of tasks'. Participants understood persistent low level disruptionaffected their own learningand the learning of others, and students developed a sense of responsibility for their learning and their peers; and had, with time, recognisedlearners who have a high level of ownership over their learning, progress faster and achieve more as demonstrated by research by Ofsted (Ofsted 2015b).

The GCSE Academyadopteda behaviourist style, using both positive and negative reinforcement through reward, commendations and high expectations of behaviour, complementedby a comprehensive disciplinary process with senior management working closely with staff and students. However,student success wasprincipally produced by the adoption of humanistic strategies revolving around positive supportive relationships with the teachers, independence and group belonging.

The local context produces a number of challenges for the GCSE Academy, recruiting from an area which reports higher levels of socio-economic deprivation, underperforming city schools with poor GCSE outcomes and lower levels of educational achievement. In such a difficult environment, in order to continue to support student achievement, the ETF $(2014,5)$ recently suggestedFE colleges should incorporate strategies to increase motivation, as 'changing mindsets'will be a key component for overcoming the challenges of supporting disengaged students to achieve success.

\section{References}

Alt, D. 2015. “College Students' Academic Motivation, Media Engagement \& Fear of Missing Out".Computers in Human Behavior, 49(2015): 111119.http://dx.doi.org/10.1016/j.chb.2015.02.057

Attwood, G. and P. Croll. 2004. Challenging Students in Further Education: Themes Arising From a Study of Innovative FE Provision for Excluded and Disaffected Young People". Journal of Further and Higher Education 28(1): 107-119. doi:10.1080/0309877032000161850

Baeten, M., F. Dochy, and K. Struyven. 2013. "The Effects of Different Learning Environments on Students' Motivation for Learning and Their Achievement".British Journal of Educational Psychology83(3): 484-501. doi:10.1111/j.2044-8279.2012.02076.x 
Baird, J. A.,J. Rose, and A. McWhirter. 2012. "So Tell Me What You Want: A Comparison of FE College and Other Post-16 Students' Aspirations". Research in Post-Compulsory Education, 17(3): 293-310.http://dx.doi.org/10.1080/13596748.2012.700095

Bennett, T. 2011. "Low Level Disruption: Can You Kick It? Yes, You Can”. Times Educational Supplement. Accessed 15 December 2014.https://www.tes.co.uk/article.aspx?storyCode $=6087267$

Berne, E. 1964. Games People Play. London: Andre Deutsch.

Berne, E. 1963. The Structure and Dynamics of Organisations and Groups. New York: J.B. Lippincott.

Bruhwiler, C., and P. Blatchford. 2011. "Effects of class size and adaptive teaching competency on classroom processes and academic outcome".Learning and Instruction 21(1): 95-108. doi:10.1016/j.learninstruc.2009.11.004

Carreira, J. 2011. "Relationship Between Motivation for Learning EFL and Intrinsic Motivation for Learning in General Among Japanese Elementary School Students". System 39(1): 90-102.doi:10.1016/j.system.2011.01.009

Census. 2011. "[name deleted to maintain the integrity of the review process]City: Key Statistics”. Accessed 15 July 2015. http://www. [name deleted to maintain the integrity of the review process /insight.org.uk/insight/key-datasets/census-2011.aspx

Centre for Social Justice (CSJ). 2013. "Requires Improvement: The Causes of Educational Failure". September 2013.http://www.centreforsocialjustice.org.uk/publications/requiresimprovement-the-causes-of-educational-failure

Cheng, D. 2011. "Effects of class size on alternative educational outcomes across disciplines". Economics of Education Review 30(5): 980 990.doi:10.1016/j.econedurev.2011.04.009

Cohen, L.,L. Manion, andK. Morrison. 2004. Research Methods in Education. $5^{\text {th }}$ ed. Oxford: Taylor and Francis.

Crutchfield, R. 1955. “Conformity and Character". American Psychologist 10(5): 191198.http://dx.doi.org/10.1037/h0040237

Daniels, E., and Arapostathis, M. 2005.“What Do They Really Want? Student Voices and Motivation Research”.Urban Education 40(1): 34-59.doi:10.1177/0042085904270421

Denscombe, M. 2010. The Good Research Guide for Small-Scale Research Projects. $4^{\text {th }}$ ed. Berkshire: Open University Press.

Department for Business Innovation \& Skills (BIS). 2012. "Skills Funding Statement 20122015".The Skills Funding Agency, December 2012.https://www.gov.uk/government/uploads/system/uploads/attachment_d ata/file/82774/bis-12-p172x-skills-funding-statement-2012-2015.pdf 
Department for Education (DfE). 2013. "2010 to 2015 Government Policy: Young People". https://www.gov.uk/government/publications/2010-to-2015-government-policy-youngpeople/2010-to-2015-government-policy-young-people

Dietrich, J., A. L. Dicke, B. Kracke, and P. Noack. 2015. "Teacher Support and its Influence on Students' Intrinsic Value and Effort: Dimensional Comparison Effects Across Subjects". Learning and Instruction 39(Oct 2015): 45-54. http://dx.doi.org/10.1016/j.learninstruc.2015.05.007

Education Funding Agency (EFA). 2014. "16 to 19 Funding: Maths and English Condition of Funding”. July 2014. www.gov.uk/government/publications

Education and Training Foundation (ETF). 2014. "Effective Practices in Post-16 Vocational Maths". December 2014. The Research Base. http://www.et-foundation.co.uk/wpcontent/uploads/2014/12/Effective-Practices-in-Post-16-Vocational-Maths-v4-0.pdf

Ewen, M., and K. J. Topping. 2012. "Personalised Learning for Young People with Social, Emotional and Behavioural Difficulties". Educational Psychology in Practice: Theory, Research and Practice in Educational Psychology 28(3): 221-239.

doi:10.1080/02667363.2012.684090

Gould, J. 2012. Learning Theory and Classroom Practice in the Lifelong Learning Sector. $2^{\text {nd }}$ ed. London: Learning Matters.

Guyan, M. 2013. "Improving Learner Motivation in Educational Settings". Training and Development, Issue October 2013. The Australian Institute of Training and

Development.www.aitd.com.au

Gravells, A., and S. Simpson. 2008. Planning and Enabling Learning in the Lifelong Learning Sector. London: Learning Matters.

Harkin, J. 2006. "Treated Like Adults: 14-16-year-olds in Further Education". Research in Post-Compulsory Education 11(3): 319-339.doi:10.1080/13596740600916559

Jasmi, A. N., and L. C.Hin. 2014."Student-Teacher Relationship and Student Academic Motivation. Journal of Interdisciplinary"Research in Education 4(1): 7582.doi:10.7603/s40933-014-0006-0

Kenny, M. E., L. Y. Walsh-Blair, D. L. Blustein, J. Bempechat and J. Seltzer. 2010. "Achievement motivation among urban adolescents: Work hope, autonomy support, and achievement-related beliefs". Journal of Vocational Behaviour 77(2): 205-212.

doi:10.1016/j.jvb.2010.02.005

Kidd, W., and G. Czerniawski. 2010. Successful Teaching 14-19: Theory, Practice and Reflection. London: Sage.

Kirby, S., M. Byra, T. Readdy, and T. Wallhead. 2015. "Effects of Spectrum Teaching Styles on College Students' Psychological Needs Satisfaction and Self-determined Motivation". European Physical Education Review May 7, 2015:120.doi:10.1177/1356336X15585010 
Mueller, S. 2013. "Teacher experience and the class size effect: Experimental evidence". Journal of Public Economics 98: 44-52. doi:10.1016/j.jpubeco.2012.12.001

Leaper, C., T. Farkas, and C. S. Brown. 2012. Adolescent Girls' Experiences and GenderRelated Beliefs in Relation to Their Motivation in Math/Science and English.Youth Adolescence 41(3): 268-282.doi:10.1007/s10964-011-9693-Z

Ledingham, D. 2008. 'I'm Not Paid To Like Them': Does a Teacher Need to Like All Children in Order to be Effective?" Times Educational Supplement. Accessed 26 November 2014.http://www.tes.co.uk/article.aspx? storycode $=2623010$

Lumby, J. 2012. "Disengaged and Disaffected Young People: Surviving the System".British Educational Research Journal 38(2): 261-279.doi:10.1080/01411926.2010.541553.

Macleod, G. 2006. "Bad, Mad or Sad: Constructions of Young People in Trouble and Implications for Interventions". Emotional and Behavioural Difficulties 11(3):155167.doi:10.1080/13632750600833791

Mezirow, J. 1997. "Transformative Learning: Theory to Practice". New Directions For Adult And Continuing Education74: 5-12. doi:10.1002/ace.7401

Morrison, A. 2010. "I Want an Education': Two Case Studies of Working-Class Ambition and Ambivalence in Further and Higher Education". Research in Post-Compulsory Education 15(1): 67-80.doi:10.1080/13596740903565376

Mouratidis, A., and A. Michou. 2011. "Self-determined Motivation and Social Achievement Goals in Children's Emotions". Educational Psychology: An International Journal of Experimental Educational Psychology 31(1): 67-86. doi:10.1080/01443410.2010.518595

Newby, P. 2010. Research Methods for Education. Essex: Pearson Education.

Nguyen, G. 2015. "A Case Study of Students' Motivation in College Algebra Courses". Community College Journal of Research and Practice 39(8): 693-707. doi:10.1080/10668926.2013.824394

Nooruddin, S., and S. Baig. 2014. "Student Behaviour Management: School Leader's Role in the Eyes of the Teachers and Students". International Journal of Whole Schooling 10(2): 1-20.http://wholeschooling.net/Journal_of_Whole_Schooling/IJWSIndex.html

O’Donnell, R. 2005. "Within the Accountability Era: Principals' Instructional Leadership Behaviours and Student Achievement". NASSP Bulletin 89(645): 5671.doi:10.1177/019263650508964505

Ofsted. 2015a. "The Framework for School Inspection”. January 2015. https://www.gov.uk/government/publications/the-framework-for-school-inspection

Ofsted. 2015b. "Learner Voice Improving Teaching Learning and Assessment: New College Pontefract". March 2015.https://www.gov.uk/government/publications/learner-voiceimproving-teaching-learning-and-assessment 
Ofsted. 2014. "Below the Radar: Low-Level Disruption in the Country's Classrooms". September 2014.www.ofsted.gov.uk/resources/140157

Ofsted. 2008. "Good Practice in Re-engaging Disaffected and Reluctant Students in Secondary Schools". October 2008.

http://webarchive.nationalarchives.gov.uk/20141124154759/http://www.ofsted.gov.uk/resou rces/good-practice-re-engaging-disaffected-and-reluctant-students-secondary-schools

Ormrod, J. 2008. Educational Psychology: Developing Learners. New Jersey: Pearson Merrill Prentice Hall

Peart, S. 2013.Making Education Work: How Black Men and Boys Navigate the Further Education Sector. London: Institute of Education Press.

Performance Panel Data (PPD) 2014. "[name deleted to maintain the integrity of the review process]". $8^{\text {th }}$ December 2014.

Petty, G. 2009. Teaching Today. $4^{\text {th }}$ ed. Cheltenham: Nelson Thornes.

Porter, N. 2015. "Crossing The Line:Improving success rates among students retaking English and maths GCSEs". August 2015. Policy Exchange.

http://www.policyexchange.org.uk/images/publications/crossing\%20the\%20line.pdf

Punch, K. 2005. Introduction to Social Research. $2^{\text {nd }}$ ed. London: SAGE Publications.

Reupert, A., and S. Woodcock. 2010. "Success and Near Misses: Pre-service Teachers' Use Confidence and Success in Various Classroom Management Strategies". Teacher and Teacher Education 26(6): 1261-1268. doi:10.1016/j.tate.2010.03.003

Roessger, K. M. 2012. "Re-Conceptualizing Adult Education's Monolithic Behaviourist Interpretation: Toward a New Understanding of Radical Behaviourism".International Journal of Lifelong Education 31(5): 569589.http://dx.doi.org/10.1080/02601370.2012.700647

Rogers, C. 2003. Client-Centered Therapy. London: Constable and Robinson.

Russell, D. 2015. "Why Are[name deleted to maintain the integrity of the review process]Schools Still Bottom of the Class?" [name deleted to maintain the integrity of the review process] Post. Accessed 15 July 2015. http://www./name deleted to maintain the integrity of the review process /post.com/city-schools-class/story-25947770-detail/story.html

Skinner, B.F. 1974. About Behaviourism. London: Jonathan Cape.

Slack, K. 2014. "Intra-class Differences in the Post-16 Educational Trajectories of Young People From Lower Socioeconomic Groups" Research in Post-Compulsory Education, 19(4): 433-449. doi:10.1080/13596748.2014.955636 
Stoughton, E. H. 2007. "How Will I Get Them to Behave?" Pre Service Teachers Reflect on Classroom Management". Teaching and Teacher Education 23(7): 1024-1037.

doi:10.1016/j.tate.2006.05.001

Stuart, K., and A. Alger. 2011. "The Use of Transactional Analysis in Secondary Education: A Case Study".Teacher Education Advancement Network Journal 3(1).http://bit.ly/xMlqKB

Wallace, S. 2007a. Getting the Buggers Motivated in FE. London: Continuum Interational.

Wallace, S. 2007b. Managing Behaviour in the Lifelong Learning Sector. $2^{\text {nd }}$ ed. London: Learning Matters.

Wallace, S. 2013. "When You're Smiling: Exploring How Teachers Motivate and Engage Learners in the Further Education Sector". Journal of Further and Higher Education 38(3): 346-360. doi:10.1080/0309877X.2013.831040

Ward, H. 2014. 'Thousands of Post-16 Students Fail to Gain a C at GCSE Maths and English'. Accessed 15 July 2015.

https://www.tes.co.uk/news/school-news/breaking-news/thousands-post-16-students-failgain-a-c-gcse-maths-and-english

Wigley, S. 2004. "Assessment of Morale in Further Education Students Studying for A-level Examinations". Journal of Further and Higher Education 28(4): 423434.doi:10.1080/0309877042000298885

Wolf, A. 2011.“Review of Vocational Education: The Wolf Report”. March 2011.The Department for Education.https://www.gov.uk/government/publications/review-ofvocational-education-the-wolf-report

\section{Figures}

Figure 1.

Berne, E. 1964. Games People Play. London: Andre Deutsch. 